\title{
Epidemiological snapshot of the mansonelliasis infection in the Amazonian riverine communities in two contiguous municipalities of Solimões river, Amazonas State, Brazil
}

Retrato epidemiológico da infecção por mansonelose em comunidades ribeirinhas da Amazônia em dois municípios contíguos do rio Solimões, Estado do Amazonas, Brasil

Retrato epidemiológico de la infección por mansonelosis en comunidades ribereñas de la Amazonia en dos municipios junto al rio Solimões, Estado de Amazonas, Brasil

Jansen Fernandes Medeiros

Laboratório de Entomologia Médica, Fiocruz Rondônia, Porto Velho, Rondônia, Brasil

Felipe Arley Costa Pessoa

Laboratório de Ecologia de Doenças Transmissiveis da Amazônia,

Instituto Leônidas e Maria Deane, Fiocruz Amazônia, Manaus,

Amazonas, Brasil
Moreno Souza Rodrigues

Núcleo de Epidemiologia e Bioestatística, Centro de Pesquisas Gonçalo Moniz, Fiocruz Bahia, Salvador, Bahia, Brasil

Marilaine Martins

Gerência de Parasitologia, Fundação de Medicina Tropical Doutor

Heitor Vieira Dourado, Manaus, Amazonas, Brasil

\begin{abstract}
This study was conducted to gather updated information on the occurrence of Mansonella ozzardi in Codajás, and report new information about filaria found in the riverine communities of Coari, Amazonas State, Brazil. The prevalence (thick blood smear) of infection was $9.4 \%$ and $22.0 \%$ in Codajás and Coari, respectively. Men (17.1\%) had a higher prevalence than women (1 1.2\%) (ANOVA $\chi^{2}=-4.93 ; p=0.02$ ); and the rates significantly increased with age (ANOVA $\left.\chi^{2}=-11.51 ; p<0.001\right)$ and in certain occupations such as farming/fishing $(29.2 \%)$ and retired $(27.6 \%)$. Municipalities located in the Solimões river have attracted large numbers of migrant workers due to oil and gas exploration in the area, and this may facilitate the spread of filariasis to other non-endemic areas.
\end{abstract}

Keywords: Mansonelliasis; Mansonella; Epidemiological Profile.

Mansonelliasis is a disease caused by the accumulation of the Mansonella filaria genus in blood vessels. The first human report case of $M$. ozzardi in Brazil was made by Deane ${ }^{1}$ during an epidemiologic survey in the City of Manaus, Amazonas State, and since then has been reported in the States of Amazonas, Roraima, Mato Grosso and Acre $^{2}$. During the 1950s, filaria were widely distributed throughout Amazonas, accompanied by high rates of filariasis in the Municipalities of the Solimões river, and more specifically in Codajás (23.9\%), Fonte Boa (17.8\%), São Paulo de Olivença (12.6\%) and Coari $(10.0 \%)^{3}$. Since that time,

\footnotetext{
Correspondence / Correspondência / Correspondencia:

Jansen Fernandes Medeiros

Fundação Oswaldo Cruz, Fiocruz-Rondônia

Rua da Beira, 7671, BR 364. Bairro: Lagoa

CEP: 76812-245 Porto Velho-Rondônia-Brazil

Phone\#: + 55 (69) 3219-6024

E-mail: imedeiro@gmail.com
}

more than 50 years passed without further researches being conducted in the Solimões river; however, there are new studies on filaria vectors in the Municipality of Manacapuru 4,5 . Subsequently, an epidemiological study of M. ozzardi in the urban and rural areas of Coarib, and even more recently, in the Municipality of Tefé have been conducted, but there are no epidemiological surveys on mansonelliasis in Codajás.

The current study was carried out in the Municipalities of Codajás and Coari between 2011 and 2012, in the region of the Solimões river, Amazonas State, which has experienced a large population that has increased because of the migratory flows due to installation of platforms used for petrol and gas extraction. It is known that mansonelliasis is endemic in these Municipalities $3,6,8,9$, where they have experienced a constant influx of people from several other regions of the country. Therefore, this study was designed to obtain updated information regarding the prevalence of M. ozzardi in the Municipalities of Codajás, and also in riverine communities of the Coari Municipality, which have not been previously studied. 
The Municipalities of Codajás (350'S 62 $3^{\prime} \mathrm{W}$ ) and Coari $\left(4^{\circ} 05^{\prime} \mathrm{S} 63^{\circ} 08^{\prime} \mathrm{W}\right)$ (Figure 1) are located approximately 297 and $363 \mathrm{~km}$, respectively, from Manaus. The study was conducted in riverine communities: Codajás - Urucurizinho, Taracua, Massaranduba, Urucurizinho II, Vale de Benção, Murituba and Vila Nova, as well as other communities located in the Municipality of Coari bordering Codajás and Tefé - Tapiri, Miriti, Vila Câmera, Camarazinho and Katua. In Codajás, a sample size was calculated using a prevalence of $18.9 \%^{6}$ design effect of 1.0 and a confidence interval of $95 \%$. The target population of this study consisted of individuals aged $\geq 3$ years old who were selected by convenience sampling methods, and were in their homes at the time when the field activities were performed. In this study, at least $30 \%$ of the population in each community was examined. A written informed consent was signed by each participant, and a parent to provide consent for children. The Ethics Committee of the Fundação de Medicina Tropical Doutor Heitor Vieira Dourado (protocol 1504/October 2010) approved the project.

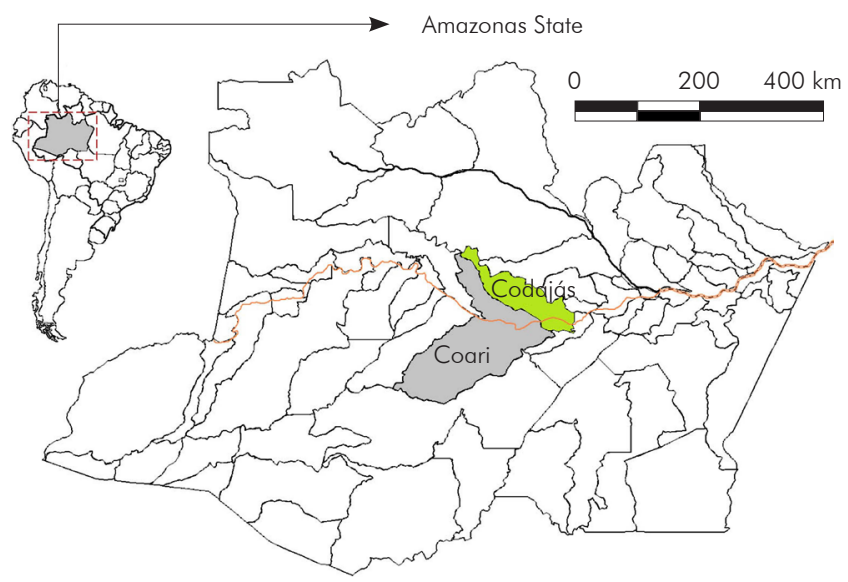

Figure 1 - Map of the studied area showing the Municipalities of Codajás and Coari, Amazonas State, Brazil

A total of 372 individuals, 245 in Codajás and 127 in Coari (average age $=27.7 \pm 19.3$ years old, range 3-86 years old) were examined for the presence of microfilariae by the thick blood smears using the following procedure. Two drops of blood (approximately $60 \mu \mathrm{L})$ were collected from each individual, they were dehemoglobinized, Giemsa stained and microscopically examined. In case of microfilaria ( $\mathrm{mf}$ ) it was found the morphological features that were compared with Post et $\mathrm{al}^{10}, \mathrm{M}$. ozzardi $\mathrm{mf}$ were also identified using the polymerase chain reaction ${ }^{11}$.

All examined individuals were grouped by gender, age (3-10, 11-20, 21-30, 31-40, 41-50, 51-60, $61-70,71-80$ and $\geq 80$ years) and occupation (farmer/ fisherman, student, retired teacher, health agent, school manager, Eletrobrás' technician and housewife). A factorial analysis of covariance (ANCOVA) adjusted to the binominal distribution of errors was performed to determine the prevalence of mansonelliasis in each occupational and age group. Thus, a full model was constructed in which the response variable was the prevalence of filariae, and the explanatory variables were group (two levels), occupation (six levels) and age (continuous variable). A step-down procedure based on Akaike information criterion values was used to determine the minimum adequate model. All analyses were performed using $R$ statistical software, and $p$-values $<0.05$ were regarded as statistically significant.

A total of 372 individuals were examined, and the unique $\mathrm{mf}$ specie found was identified as $M$. ozzardi. M. ozzardi mf was found in 23 (9.4\%) and 28 (22.0\%) individuals in Codajás and Coari, respectively. The highest prevalences of infection were found in the communities of Vila Nova $(38.1 \%$; $95 \% \mathrm{Cl} 19.5-59.8)$ and Katuá (72.7\%; 95\% Cl 42.2-92.5) (Table 1). The prevalence of infection was significantly higher in men $(17.1 \%$ - 27 microfilaraemic/158 examined) than in women $(11.2 \%-24 / 214)$ (ANOVA $\chi^{2}=-4.93$; $\mathrm{p}=0.02)$, and increased significantly according to age (ANOVA $\chi^{2}=-11.51 ; p<0.001$ ), with higher prevalences found in individuals aged $\geq 30$ years old (Figure 2). A contrast analysis for infection prevalence based on occupation showed four different groups, with the rates of infection being highest among farmers/fishermen (29.2\%) and retired (27.6\%), others $(15.0 \%)$ and students (1.8\%) (ANOVA $\chi^{2}=-61.37$; $\mathrm{p}<0.001)$. It is noteworthy that no significant interaction among the different variables could be identified (Table 2).

Table 1 - Prevalence of $M$. ozzardi in riverine communities in the Municipalities of Codajás and Coari, Amazonas State, Brazil

\begin{tabular}{lccc}
\hline Communities & Total/Positive & Prevalence & $95 \%$ IC \\
\hline Codajás & & & \\
Urucurizinho & $49 / 5$ & 10.2 & $3.8-21.2$ \\
Taracua & $21 / 1$ & 4.7 & $0.2-21.3$ \\
Massaranduba & $28 / 0$ & 0.0 & $0-10.1$ \\
Urucurizinho II & $31 / 1$ & 3.2 & $0.2-14.9$ \\
Vale de Benção & $17 / 2$ & 11.7 & $2.0-33.7$ \\
Murituba & $80 / 6$ & 7.5 & $3.1-14.9$ \\
Vila Nova & $21 / 8$ & 38.1 & $19.5-59.8$ \\
Coari & & & \\
Tapiri & $7 / 2$ & 28.6 & $5.1-67.0$ \\
Miriti & $27 / 3$ & 11.1 & $2.9-27.3$ \\
Vila Camera & $65 / 11$ & 16.9 & $9.2-27.5$ \\
Camarazinho & $17 / 4$ & 23.5 & $7.9-47.5$ \\
Katua & $11 / 8$ & 72.7 & $42.2-92.5$ \\
\hline
\end{tabular}




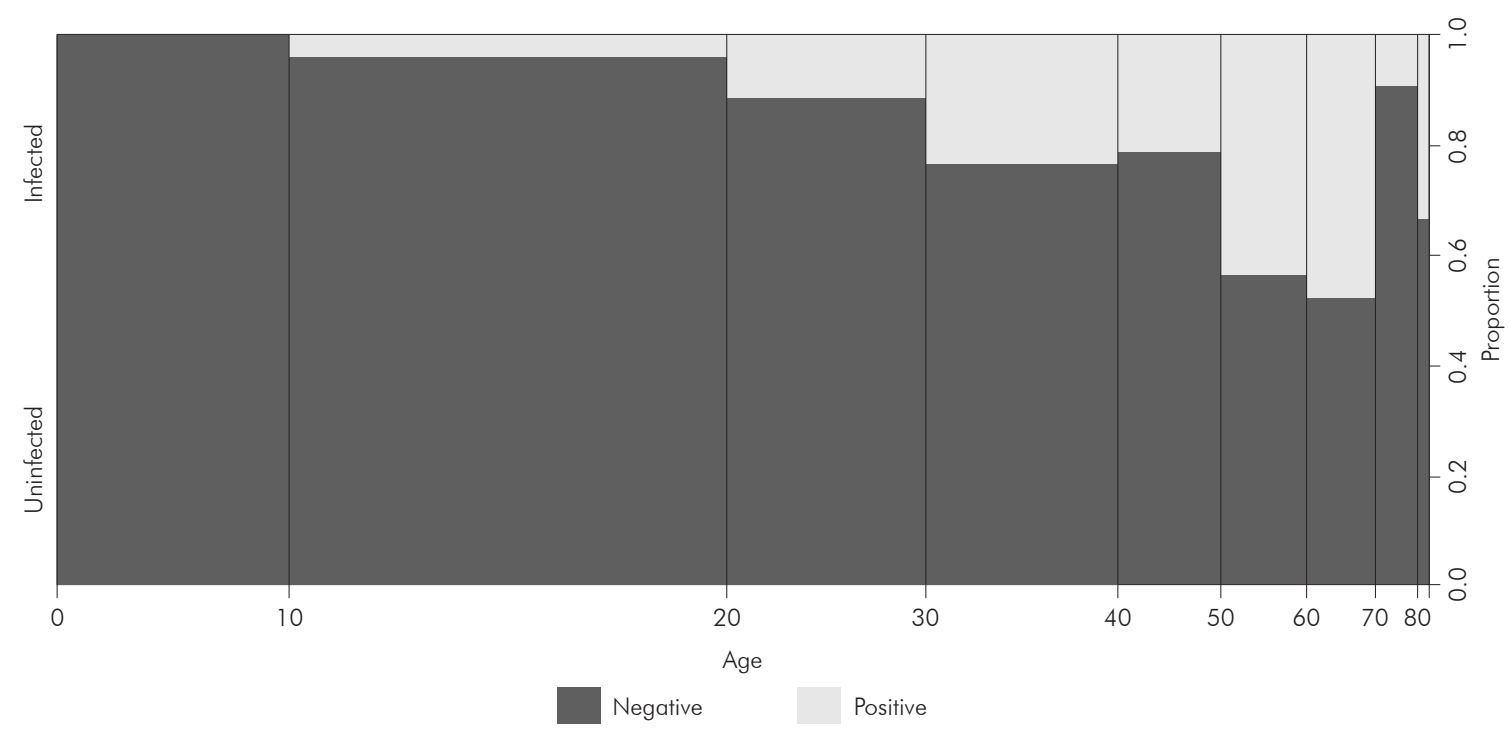

Figure 2 - Parasitized and non-parasitized individuals, according to age, in the Municipalities of Codajás and Coari, Amazonas State, Brazil

Table 2 - Factorial analysis of covariance for $M$. ozzardi prevalence in communities along the Solimões river in Codajás and Coari, Amazonas State, Brazil

\begin{tabular}{lcccc}
\hline \multirow{2}{*}{ Variable } & Level & \multicolumn{3}{c}{ ANOVA } \\
\cline { 3 - 5 } Gender & Male & $\chi^{2}$ & Contrast* $^{*}$ & p-value \\
& Female & -4.93 & - & $0.02^{\dagger}$ \\
& Farmer/fishermen & & & \\
Retired & Others & & $\mathrm{a}$ & \\
Occupation & Student & -61.37 & $\mathrm{~b}$ & $0.001^{\dagger}$ \\
& & & $\mathrm{c}$ & \\
Age & & -11.51 & - & $<0.001^{\dagger}$ \\
Gender: age & & 0.13 & - & 0.71 \\
Gender: occupation & & -3.44 & - & 0.75 \\
Age: occupation & & -6.34 & - & 0.50 \\
\hline
\end{tabular}

*Different letters indicates statistical difference $(p<0.05)$; ${ }^{\dagger}$ Statistical difference $(p<0.05)$.

In Codajás, the general prevalence of mansonelliasis was $9.4 \%$ (23/245), and filaria-infected individuals were found in six of seven communities examined. The initial surveys for filariasis in Codajás had been conducted by Lacerda and Rachou ${ }^{3}$ and it was found microfilariae present in $23.9 \%$ of the examined individuals. Later surveys found filarial infection rates of $56.7 \%, 41.4 \%$, and $45.9 \%$, respectively, as determined by simultaneous diagnoses using thick blood smears and Knott methods ${ }^{12,13,14}$. Occasional cases of filariasis were reported by local health services during malaria surveys. The prevalence of filariasis in the Municipality of Coari was $22 \%(28 / 127)$, and microfilariae-infected individuals were also found in all the communities examined. M. ozzardi has been reported to be endemic in Coari since the first records ${ }^{3}$. Those records showed prevalences ranging from $10 \%$ to $17.8 \%$; however, the most recent reports show microfilaremia prevalences of $18.9 \%, 18.2 \%$, and $26.4 \% 6,8,9$. The infection prevalences which have persisted over the years in Codajás, and more clearly in Coari, are directly related to the lack of policies for treatment of mansonelliasis. This neglect has permitted circulation of the parasite by black flies, which are vectors for M. ozzardi in Brazil. These flies are highly anthropophilic, and routinely live along rivers in Amazonas 5,6. Some Amazonas' municipalities have shown a constant infection rate throughout the years, while the rate has increased in other areas. For example, along the river Purus, increasing rates of microfilariae infection have been reported in the Municipality of Lábrea $(4.4 \% \text {, and } 20.7 \%)^{15,16}$.

The higher prevalence of infection in men is directly related to their greater levels of participation in daily activities such as agriculture and fishing, which increase their exposure to black flies,12,15. Additionally, older individuals who have always worked outside will have a greater cumulative exposure to microfilariae vectors, which can lead to greater rates of infection ${ }^{6}$. This profile of M. ozzardi commonly occurred in Amazonas, and reflects the daily lives and activities of people in the riverine population who constantly expose themselves 
to vector stings. Furthermore, there is also the risk of developing multiple filaria infections involving both male and female macrofilariae. Such infections can serve to maintain circulating populations of microfilariae, and thus the disease transmission cycle.

Our current data confirm that over the years, mansonelliasis has been perpetuated in Codajás and Coari due to the non-implementation of public policies regarding treatment. Beyond the present damage caused to the public health by that infection in the current population, there is also the possibility that filaria may expand their range of infection into non-endemic areas. Such expansion might be facilitated by the large number of workers who temporarily live in these Municipalities, and then return to their regions of origin where there is the presence of vectors.

\section{ACKNOWLEDGMENTS}

The authors would like to thank the Fundação Nacional de Saúde in the Municipality of Codajás and Coari for the logistical support. To Ademir Roberto Lopes Soares and Maria do Perpétuo Socorro dos Santos for assistance during for field research.

\section{FINANCIAL SUPPORT}

Fundação de Amparo à Pesquisa do Estado do Amazonas (Edital PPSUS FAPEAM/SUSAM/MS/CNPq 007/2009).

\section{Retrato epidemiológico da infecção por mansonelose em comunidades ribeirinhas da Amazônia em dois municípios contíguos do rio Solimões, Estado do Amazonas, Brasil RESUMO}

Este estudo foi realizado com objetivo de atualizar a prevalência de Mansonella ozzardi em Codajás e relatar novas informações sobre a filaria encontrada nas comunidades ribeirinhas de Coari, Estado do Amazonas, Brasil. As prevalências (diagnóstico de gota espessa) da infecção foram de 9,4\% e 22,0\% em Codajás e Coari, respectivamente. Os homens $(17,1 \%)$ apresentaram maiores prevalências do que as mulheres $(11,2 \%)$ (ANOVA $\chi^{2}=-4,93, p=0,02$ ). Essas prevalências aumentaram significativamente com a idade (ANOVA $\chi^{2}=-11,51, p<0,001$ ) e em determinadas ocupações como os agricultores/pescadores $(29,2 \%)$ e aposentados $(27,6 \%)$. Os Municípios do rio Solimões têm atraído um grande número de trabalhadores migrantes, devido à exploração de petróleo e gás e isso pode facilitar a disseminação da filariose para outras áreas não endêmicas.

Palavras-chave: Mansonelose; Mansonella; Perfil Epidemiológico.

\section{Retrato epidemiológico de la infección por mansonelosis en comunidades ribereñas de la Amazonia en dos municipios junto al rio Solimões, Estado de Amazonas, Brasil RESUMEN}

Este estudio fue realizado con el objetivo de actualizar la prevalencia de Mansonella ozzardi en Codajás y relatar nuevas informaciones sobre la filaria encontrada en las comunidades ribereñas de Coari, Estado de Amazonas, Brasil. Las prevalencias (diagnóstico de gota gruesa) de infección fueron $9,4 \%$ y 22,0\% en Codajás y Coari, respectivamente. Los hombres $(17,1 \%)$ presentaron mayores prevalencias que las mujeres $(11,2 \%)$ (ANOVA $\chi^{2}=-4,93, p=0,02$ ). Estas prevalencias aumentaron significativamente con la edad (ANOVA $\chi^{2}=-11,51, p<0,001$ ) y en determinadas ocupaciones como agricultores/pescadores $(29,2 \%)$ y jubilados $(27,6 \%)$. Los municipios de rio Solimões han atraído gran número de trabajadores migrantes, debido a la explotación de petróleo y gas, lo cual puede facilitar la diseminación de la filariasis para otras áreas no endémicas.

Palabras clave: Mansoneliasis; Mansonella; Perfil Epidemiológico.

\section{REFERENCES}

1 Deane MP. Sobre a incidência de filárias humanas em Manaus, Estado do Amazonas. Rev Serv Esp Saude Publica. 1949;2(3):849-58.

2 Medeiros JF, Pessoa FAC, Camargo LMA. Mansonelliasis: a Brazilian neglected disease. Rev Pat Trop. 2014 Jan-Mar;43(1):1-6.

3 Lacerda NB, Rachou RG. Filarioses humanas nas sedes municipais do estado do Amazonas e territórios do Acre, Guaporé e Rio Branco. Rev Bras Malariol Doenças Trop. 1956;8:437-42.
4 Medeiros JF, Py-Daniel V. Atividade hematofágica diária e taxa de infecção natural de Cerqueirellum argentiscutum (Shelley \& Luna Dias) (Diptera: Simuliidae) por Mansonella ozzardi (Manson) (Nematoda: Onchocercidae) em uma comunidade do rio Solimões, Amazonas, Brasil. Entomol Vectores. 2003;10(1):9-20.

5 Medeiros JF, Py-Daniel V. Seasonality, parity rates and transmission indices of Mansonella ozzardi (Manson) (Nematoda: Onchocercidae) by Cerqueirellum argentiscutum (Shelley \& Luna Dias) (Diptera: Simuliidae) in a lower Solimões River community, Amazonas, Brazil. Acta Amaz. 2004;34(2):201-7. 
6 Martins M, Pessoa FAC, Medeiros MB, Andrade EV, Medeiros JF. Mansonella ozzardi in Amazonas, Brazil: prevalence and distribution in the municipality of Coari, in the middle Solimões River. Mem Inst Oswaldo Cruz. 2010 May; 105(3):246-53.

7 Medeiros JF, Costa CA, Lima AM, Pessoa FAC. Mansonella ozzardi (Nematoda: Onchocercidae) in the riverine population from Tefé River, Amazonia, Brazil. Rev Soc Bras Med Trop. 2014 JanFeb;47(1):113-5.

8 Vianna LMM, Martins M, Cohen MJ, Cohen JM, Belfort Jr R. Mansonella ozzardi corneal lesions in the Amazon: a cross-sectional study. BMJ Open. 2012 Nov;2(6):e001266.

9 Cohen JM, Ribeiro JAS, Martins M. Acometimento ocular em pacientes com mansonelose. Arq Bras Oftalmol. 2008 mar-abr;71 (2):167-71.

10 Post RJ, Adams ZA, Shelley AJ, Maia-Herzog $M$, Dias APAL, Coscarón $S$. The morphological discrimination of microfilariae of Onchocerca volvulus from Mansonella ozzardi. Parasitology. 2003 Jul;127(1):21-7.
11 Medeiros JF, Almeida TPA, Silva LBT, Rubio JM, Crainey JL, Pessoa FAC, et al. A field trial of a PCRbased Mansonella ozzardi diagnosis assay detects high-levels of submicroscopic $M$. ozzardi infections

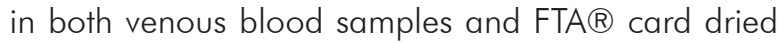
blood spots. Parasit Vectors. 2015 May;8(280): 1 - 15.

12 Batista D, Cerqueira NL, Moraes MAP. Epidemiologia da mansonelose em localidade do interior do Amazonas. Rev Assoc Med Bras. 1960;6:176-84.

13 Moraes MAP. Contribuição ao estudo da mansonelose do Amazonas. Hospital. 1958 dez;54(6):887-92.

14 Oliveira WR. Mansonelose e sua sintomatologia. Hospital. 1961 mar;59(3):129-34.

15 Medeiros JF, Py-Daniel V, Barbosa UC. Prevalence of Mansonella ozzardi among riverine communities in the municipality of Lábrea, Amazonas state, Brazil. Rev Soc Bras Med Trop. 2011 Mar-Apr;44(2): 186-90.

16 Shelley AJA. Preliminary survey of the prevalence of Mansonella ozzardi in some rural communities on the river Purus, state of Amazonas, Brazil. Ann Trop Med Parasitol. 1975 Sep;69(3):407-12. 